\title{
New taxa of Hesperantha (Iridaceae: Crocoideae) from the southern African winter rainfall region and a review of the $H$. pilosa complex
}

\author{
P. GOLDBLATT ${ }^{1,2}$ and J.C. MANNING ${ }^{2,3}$
}

Keywords: Iridaceae, Hesperantha, new species, southern Africa, taxonomy, winter rainfall zone

\section{ABSTRACT}

\begin{abstract}
The southern and tropical Africa genus Hesperantha Ker Gawl., now with 85 species, is distinguished in subfam. Crocoideae by the style dividing into relatively long, usually laxly spreading style branches at or shortly below the mouth of the perianth tube (rarely well within the tube or above the mouth of the tube) and, with a few exceptions, by hard, woody corm tunics. We describe three new species here. H. dolomitica Goldblatt \& J.C.Manning, a narrow endemic of limestone outcrops on slopes north of the Vars River in the Knersvlakte, Western Cape, has the bell-shaped corms characteristic of the small sect. Hesperantha but is distinctive in the section in its pure white perianth with relatively long tube and soft-textured, falcate to distally trailing leaves. H. laxifolia Goldblatt \& J.C.Manning from the Pakhuis Mtns, Western Cape, stands out in sect. Hesperantha in its prostate, somewhat succulent foliage leaves, and spikes of $2-5$ white flowers with unusually short filaments less than $1 \mathrm{~mm}$ long and particularly short anthers, $\pm 4 \mathrm{~mm}$ long. The short style branches, $\pm 4 \mathrm{~mm}$ long, remain suberect rather than laxly spreading. $H$. secunda Goldblatt \& J.C.Manning from the Roggeveld Escarpment, Northern Cape, has until now been included in $H$. pilosa but differs in its secund spike of nodding flowers with short style branches, and leaves with broadly winged margins. We also recognize a new subsp. bracteolata (R.C.Foster) Goldblatt \& J.C.Manning of H. pilosa (L.f.) Ker Gawl. for populations of plants with diurnal flowers with usually blue or purple (occasionally white) tepals lacking dark pigmentation on the reverse. With additional material to hand, we reduce blue-flowered $H$. ciliolata Goldblatt to synonymy in subsp. bracteolata and report range extensions for $H$. pilosa subsp. pilosa, now recorded as far east as the Langeberg near Cloete's Pass.
\end{abstract}

\section{INTRODUCTION}

Hesperantha Ker Gawl., now with 85 species (Goldblatt 1984, 2003; Goldblatt \& Manning 2007a) is one of the larger genera of Iridaceae subfam. Crocoideae Burnett. Its range extends from the southwestern Cape and Namaqualand, South Africa, through eastern southern Africa to East Africa, Ethiopia and Cameroon, but is centred in the southern African winter rainfall zone. Hesperantha is distinguished by the style dividing shortly below the mouth of the perianth tube (rarely within or well above the mouth of the tube) into relatively long, \pm straight, usually laxly spreading style branches and, with a few exceptions, by hard, woody corm tunics (Goldblatt \& Manning 2008). Here we describe three new species of the genus, two from the western half of Western Cape and one from Northern Cape. H. dolomitica Goldblatt \& J.C.Manning, a narrow endemic of limestone outcrops in the Knersvlakte of southern Namaqualand, stands out in its long, narrow, falcate leaves, and pure white flowers with relatively long tube and tepals remaining cupped when fully expanded. H. laxifolia Goldblatt \& J.C.Manning from the Pakhuis Mtns of northwestern Western Cape has prostrate, soft-textured basal leaves and among the smallest flowers in the genus, the perianth tube about 5 $\mathrm{mm}$ long, tepals $10 \mathrm{~mm}$ long and filaments less than 1

${ }^{1}$ B.A. Krukoff Curator of African Botany, Missouri Botanical Garden, P. O. Box 299, St. Louis, Missouri 63166, USA. E-mail: peter.goldblatt@mobot.org.

${ }^{2}$ Research Centre for Plant Growth and Development, School of Life Sciences, University of KwaZulu-Natal, Pietermaritzburg, Private Bag X01, Scottsville 3209, South Africa.

${ }^{3}$ Compton Herbarium, South African National Biodiversity Institute, Private Bag X7, 7735 Claremont, Cape Town. E-mail: j.manning@ sanbi.org.za. mm long. Both H. dolomitica and H. laxifolia have bellshaped corms with a flat base and margins finely serrated, placing them in sect. Hesperantha of the genus (Goldblatt 1982). We provide a revised key to the section, now with eleven species. In the $H$. pilosa (L.f.) Ker Gawl. complex of sect. Concentricae Goldblatt, we recognize the new subsp. bracteolata (R.C.Foster) Goldblatt \& J.C.Manning for populations of $H$. pilosa (L.f.) Ker Gawl. with diurnal flower phenology and mostly blue or purple (rarely white) flowers (vs. usually flowers white with dark pigmentation on the reverse of the tepals and crepuscular floral phenology). New collections of subsp. bracteolata have rendered the distinction between it and blue-flowered $H$. ciliolata Goldblatt untenable and we reduce the latter to synonymy. Range extensions for H. pilosa subsp. pilosa show that it occurs near Swellendam and in the eastern Langeberg near Cloete's Pass, well to the east of its recorded stations. Lastly, we recognise the new species $H$. secunda (H. sect. Concentricae) for a collection from near Middelpos until now included in $H$. pilosa but differing from that species in its secund spike of nodding flowers with curved perianth tube and relatively short style branches $\pm 4 \mathrm{~mm}$ long, and leaves with winged leaf margins and raised main vein.

\section{NEW SPECIES OF SECT. HESPERANTHA}

1. Hesperantha dolomitica Goldblatt \&
J.C.Manning, sp. nov.

TYPE.-Western Cape, 3118 (Vanrhynsdorp): Knersvlakte, Farm Varsche Rivier 260, 300 m north of Vars River, south-facing limestone crevices, ledges and moss pads, 76 m, (-BC), 25 July 2012, Helme 7425 (NBG, holo.).

Plants mostly 180-250 mm high. Corm bell-shaped with flat base; tunics dark brown, softly woody, outer 
layers irregularly broken, margins minutely toothed. Stem unbranched, glabrous. Leaves 4, lower two basal, \pm linear, flaccid, \pm falcate, third leaf inserted shortly above ground and sheathing stem for most of its length, uppermost leaf bract-like, inserted on upper third of stem, entirely sheathing, basal leaf blades 60-80 × 3-4 $\mathrm{mm}$. Spike 2-4-flowered, outer bract mostly $12-15 \mathrm{~mm}$ long, pale green, evidently becoming dry and pale strawcoloured during flowering, inner slightly shorter, with 2 green keels, narrowed distally and sometimes recurved above. Flowers radially symmetric, white without darker colouring on reverse, tepals remaining cupped when fully open, sweetly scented; perianth tube narrowly funnel-shaped, 12-14 mm long; tepals subequal, elliptic, $12-14 \times 4 \mathrm{~mm}$. Stamens with filaments $\pm 3 \mathrm{~mm}$ long; anthers $6-8 \mathrm{~mm}$ long, pale yellow; pollen yellow. Ovary ovoid, 2.5-3.0 mm long; style dividing at mouth of tube, branches $\pm 7 \mathrm{~mm}$ long, diverging. Capsules and seeds unknown. Flowering time: July, probably also August; flowers begin to open $\pm 12: 30$ and are fully open later in the day, time of closing not known.

Distribution and ecology: local in the Knersvlakte in southern Namaqualand, Hesperantha dolomitica is restricted to limestone outcrops north of the Vars River (Figure 1). Mostly wedged in cracks in the rocks, plants are also occasionally found in loamy, red soils at the base of the south-facing limestone cliffs. We regard the species as EN (Endangered), in light of its narrow range, very particular habitat requirements, small total population, and potential for the mining of its limestone habitat.

Diagnosis: $H$. dolomitica has the bell-shaped corms with a flat base that are characteristic of sect. Hesperantha (Goldblatt 2003). Within the section, H. dolomitica is recognized by its relatively large, pure white flowers with tepals remaining cupped even when fully expanded and without the darker pigmentation on the outside of the tepals that is a common feature in white-flowered species of the genus. The perianth tube and tepals are about the same length, 12-14 mm long, relatively large for sect. Hesperantha. Additional observations are needed to confirm the ultimate orientation of the tepals, which may not occur until after dark, but we believe the tepals remain cupped as they achieved this orientation by early afternoon and had remained unchanged by 17:00 (N. Helme pers. comm.).

Hesperantha dolomitica is one of a growing number of very narrow endemic plant species discovered on limestone substrates in the Knersvlakte. In Iridaceae these now include Babiana carminea Goldblatt \& J.C.Manning (2007b), Ixia acaulis Goldblatt \& J.C.Manning (1993) and Moraea deserticola Goldblatt \& J.C.Manning (1986) as well as $H$. dolomitica. All these species, and up to fourteen additional endemics in other families, are endangered if plans for mining the limestone substrate on which these plants grow come to fruition.

\section{Additional specimen seen}

WESTERN CAPE-3118 (Vanrhynsdorp): Knersvlakte, Farm Varsche Rivier Extension A 227, steep, S-facing crevices in limestone ridge, (-BC), 25 July 2012, Helme 7424 (MO, NBG).

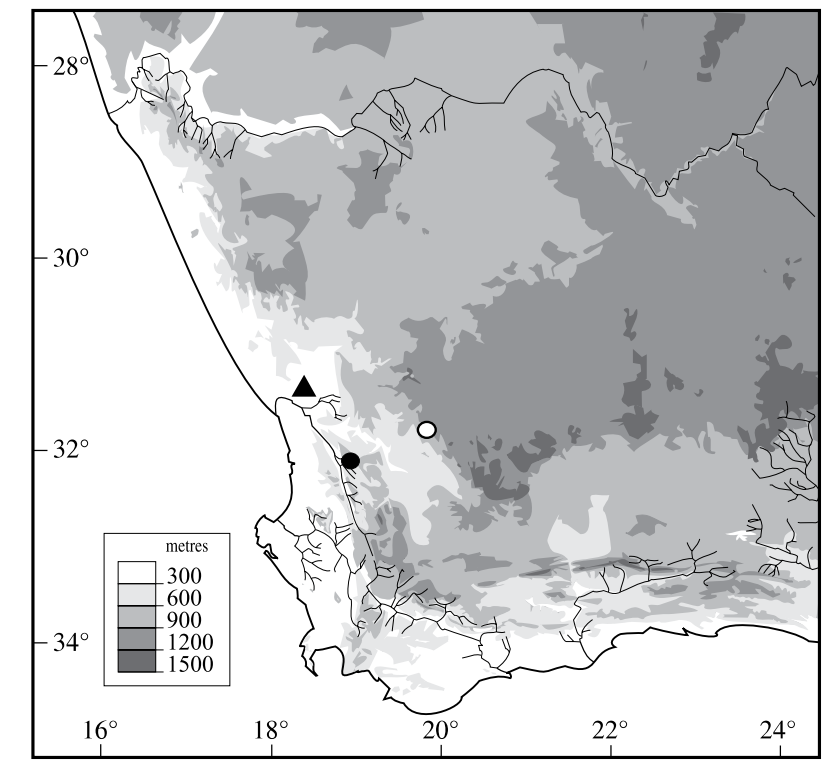

FIGURE 1.-Distribution of Hesperantha dolomitica, $\mathbf{\Delta} ;$ H. laxifolia, $\bullet$; and $H$. secunda, o.

\section{Hesperantha laxifolia Goldblatt \& J.C.Manning,} sp. nov.

TYPE.-Western Cape, 3219 (Wuppertal): mountains north of Pakhuis Pass, occasional among sandstone rocks on south-facing slopes and banks, (-AA), 12 Oct. 2012, Goldblatt \& Porter 13877 (NBG, holo.; K, MO, PRE, iso.).

Plants 90-160 mm high. Corm bell-shaped with flat, sometimes oblique base, $10-15 \mathrm{~mm}$ diam.; tunics dark brown, inner layers \pm woody, outer layers becoming soft and broken, margins minutely serrated. Stem unbranched, glabrous. Leaves 3(4), lower 2 leaves usually prostrate (suberect in deeply shaded sites), fleshy, flaccid, obtuse, 50-70 × 4-5 mm, with main vein raised, margins pale, slightly thickened, third leaf sheathing lower $1 / 3$ of stem, slightly inflated, fourth leaf (when present) on upper part of stem, bract-like and entirely sheathing. Spike mostly 2-3(5)-flowered, outer bract 8-9 mm long, green flushed red distally, inner slightly shorter to \pm as long, partly membranous with 2 green keels, notched apically. Flowers white, outer and sometimes inner tepals red to brown outside, rose-scented; perianth tube narrowly cylindric, slightly expanded near apex, $\pm 5 \mathrm{~mm}$ long; tepals subequal, elliptic, $\pm 10 \times 4$ $\mathrm{mm}$. Stamens with filaments $\pm 0.5 \mathrm{~mm}$ long; anthers \pm $4 \mathrm{~mm}$ long, erect, pale yellow; pollen white. Ovary globose, $\pm 2.5 \mathrm{~mm}$ long; style dividing $\pm 1 \mathrm{~mm}$ below mouth of tube, branches $\pm 2.5 \mathrm{~mm}$ long, arching upward, reaching to slightly below middle of anthers. Capsules and seeds unknown. Flowering time: September to late October; opening \pm 18:00, closing \pm 21:00-21:30. Figure 2 .

Distribution: so far known from a single collection in the Pakhuis Mtns (Figure 1), in peaty and loamy sand in rocky sites, mainly on shady, south-facing slopes. As far as we can determine, Hesperantha laxifolia has a very limited range in the ridges north of Pakhuis Pass, and has not been recorded south of the Pass, an area that has 


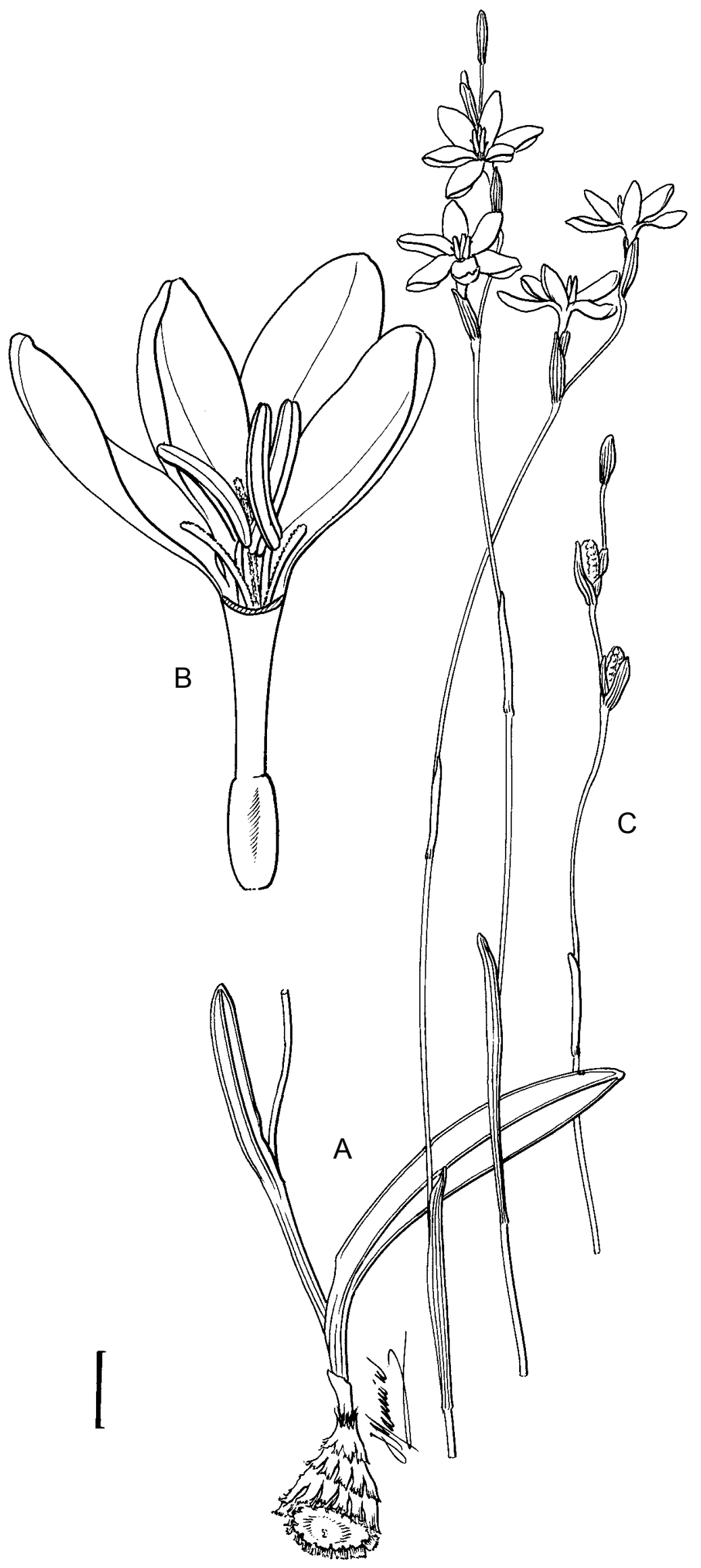

FIGURE 2.-Hesperantha laxifolia, Goldblatt \& Porter 13877 (NBG). A, flowering plant; B, flower detail; C, capsules. Scale bar: A, C, 10 mm; B, 2 mm. Artist: J.C. Manning. 
been moderately well botanized. The narrow range of the species falls within a declared Wilderness Area.

Diagnosis: with white, crepuscular flowers typical of the genus, Hesperantha laxifolia can be distinguished by its usually small flowers, the tepals $\pm 10 \mathrm{~mm}$ long and the tube only half as long. Particularly unusual, the short stamens have filaments only about 0.5 long and anthers $\pm 4 \mathrm{~mm}$ long. The style divides just below the mouth of the tube into style branches only $2.5 \mathrm{~mm}$ long, likewise unusually small for the genus. The two basal leaves are slightly succulent and normally prostrate (the feature for which the species is named), although these leaves may be ascending to suberect in damp, shady situations. The bell-shaped corms with the tunic margins finely toothed are typical of sect. Hesperantha (Goldblatt 1984), but we have no hypothesis concerning the immediate relationships of $H$. laxifolia. The only other species of the genus with prostrate leaves, $H$. montigena Goldblatt, from the Hex River and Riviersonderend Mtns, has much larger flowers with a perianth tube $12-15 \mathrm{~mm}$ long and tepals 14-16 $\mathrm{mm}$ long, thus about as long as the tube, and the corms are asymmetric, placing it in sect. Concentrica Goldblatt.

Key to species of sect. Hesperantha (species with corms triangular in outline to bell-shaped, with a flat base horizontal or obliquely oriented)

1. Corm base usually with prominent radiating spines or margins toothed; flowers diurnal, closing in late afternoon; perianth white or pink to reddish purple, rarely yellow:

2. Perianth tube 6-11 mm long. .......... pauciflora G.J.Lewis

2'. Perianth tube $15-35 \mathrm{~mm}$ long:

3. Plants acaulescent; perianth white with dark markings at base of tepals, tube (15-)30-45 mm long; anthers 3-5 mm long. ..................... luticola Goldbl.

3'. Plants usually caulescent; perianth uniformly deep pink, tube 15-25 mm long; anthers (4.0-)5.5-7.0 mm long . ..................... H. latifolia (Klatt) M.P.deVos

1'. Corm base with small teeth or scarcely serrated and usually without prominent spines; flowers crepuscular, opening in late afternoon or after sunset; perianth white, cream or pale yellow:

4. Style dividing at or below middle of perianth tube; style branches and sometimes anthers partly or completely included in perianth tube:

5. Flowers $20-25 \mathrm{~mm}$ diam. with tepals $10-12 \mathrm{~mm}$ long; stamens and style branches fully included in perianth

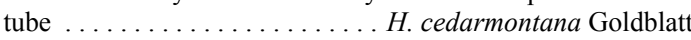

5'. Flowers $\pm 18 \mathrm{~mm}$ diam. with tepals $9-10 \mathrm{~mm}$ long; anthers exserted, but style branches reaching only to mouth of tube. . . . . . . . . . . . . . ...H. saldanhae Goldblatt

4'. Style dividing just below mouth of perianth tube; anthers and style branches fully exserted and filaments usually at least partly exserted from perianth tube:

6. Flowers small, secund on straight spike; perianth tube slightly curved, 4-6 mm long; tepals 4-7 mm long; leaves either plane and sometimes with crisped margins, or terete to ovoid in cross section and hollow; seeds with sharp angles (minute wings) and seed coat with whitish spongy cells . . . . . . . . . . H. spicata (Burm.f.) N.E.Br.

6'. Flowers small to large, not obviously secund, on straight or flexuose spike; perianth tube straight, (5-)7-14 mm long; tepals 6-18 $\mathrm{mm}$ long; leaves plane with straight margins; seeds globose or sides lightly flattened by pressure, seed coat dark brown:

7. Plants with 3 basal leaves and without cauline leaves; perianth tube $12-16 \mathrm{~mm}$ long; tepals $6-10 \mathrm{~mm}$ long, always shorter than tube; flowers pale yellow. . . . . . . $\ldots \ldots \ldots \ldots \ldots \ldots \ldots . \ldots . \ldots . . . \ldots$ sufflava Goldblatt

7'. Plants with 2 or more basal leaves and usually an additional 1 or 2 sub-basal or cauline, largely sheathing leaves; perianth tube 5-14 mm long; tepals (9-)12-18 $\mathrm{mm}$ long, usually longer than tube; flowers white, cream or yellow:

8. Foliage leaves 2 , usually prostrate, semi-succulent; filaments $<1 \mathrm{~mm}$ long . . . . . . . . . . . . . . . . . . . . . . . . . . . . . laxifolia Goldblatt \& J.C.Manning

8 '. Foliage leaves 3 , erect or falcate, not noticeably succulent; filaments $\geq 2 \mathrm{~mm}$ long:

9. Tepals uniformly white on reverse, ascending and cupped when fully open; perianth tube 12-14 $\mathrm{mm}$ long, \pm as long as tepals; leaves falcate to trailing . . .............H. dolomitica Goldblatt \& J.C.Manning

9'. Outer or all tepals flushed red to brown outside, spreading horizontally when fully open; perianth tube 4-12 mm long, shorter than tepals; leaves falcate to trailing:

10. Leaves narrow, 1-2 mm wide; perianth tube 10-12 $\mathrm{mm}$; plants of shallow soils on sandstone pavement. . . . . . . . . . H. lithicola J.C.Manning \& Goldblatt

10'. Leaves broader, 4-8 mm wide; perianth tube 4-9 $\mathrm{mm}$ long; plants of deeper clay or sandy soils:

11. Bracts green, rounded to truncate and often with reddish margin; leaves usually at least 4; flowers usually remote from leaves, borne on upper third of the stem... . . . . . . . . . . . . . . . . . .......... falcata (L.f.) Ker Gawl.: typical form

11'. Bracts green or becoming membranous and dry above, and then \pm acute; leaves often only 3 ; flowers usually borne close to leaves and from about middle of stem .......H. falcata:pentheri Baker and trifolia Baker forms (Goldblatt 2003).

\section{NEW TAXA IN THE HESPERANTHA PILOSA COMPLEX (SECT CONCENTRICAE)}

Relatively widespread in the southern African winterrainfall zone, Hesperantha pilosa was recorded by Goldblatt (1984, as subsp. pilosa) from the Bokkeveld Mtns in Northern Cape south to the Cape Peninsula and east to Bredasdorp and Riviersonderend in Western Cape. $H$. pilosa subsp. latifolia Goldblatt was raised by Goldblatt (1987) to species rank as H. pseudopilosa Goldblatt and is excluded from this discussion. As currently circumscribed then, $H$. pilosa consists of two distinct morphs. Those from the Bokkeveld Mtns, Roggeveld and Klein Roggeveld extending south to Touws River have diurnal flowers with a blue to purple (rarely white) perianth with the reverse of the tepals not strongly marked in contrasting colour; whereas those from the central Cedarberg south to southern Western Cape have crepuscular flowers with a white (rarely pale to deep lilac) perianth with the tepals coloured brown to dull red or purple outside.

Goldblatt (2003) drew attention to the two colour morphs and noted some minor differences; particularly that the flowers of blue to purple flowered plants 
have ascending to suberect anthers and often somewhat longer style branches than those of white flowered plants, which have the anthers spreading horizontally. Although Goldblatt then suggested that the two morphs should be recognized taxonomically, he expressed uncertainty that the blue- to purple-flowered morphs were monophyletic given that some plants with pale lilac flowers had been recorded in the Darling area of Western Cape; thus nested within the range of the white-flowered plants. Differences in pigmentation patterns between the blue-flowered southern and northern populations now lead us to consider that the populations with diurnal flowers and mostly a blue or purple perianth from the Bokkeveld Mtns and Roggeveld are most likely monophyletic, and it seems useful to recognize them as a separate taxon. Two names at species rank are available for these populations, $H$. puberula Schltr. ex R.C.Foster from the Bokkeveld Mtns and H. bracteolata R.C.Foster from near Sutherland (Foster 1948). We now treat $H$. pilosa as comprising two subspecies, subsp. pilosa and subsp. bracteolata (R.C.Foster) Goldblatt \& Manning, preferring subspecies rank because of the weak morphological differences between them.

Our review has brought to attention the morphologically similar Hesperantha ciliolata Goldblatt, which was distinguished from blue-flowered $H$. pilosa by its narrower, strongly ribbed leaf blades, oval in cross section, with short, spreading cilia. Typical $H$. pilosa was distinguished by its leaves with rather longer, softer cilia. New collections of what we are now calling subsp. bracteolata have bridged the differences between the two taxa. A collection from Driefontein-se-Berg, southwest of Calvinia [Goldblatt \& Manning 13999 (NBG)], has the ribbed leaf blades typical of $H$. ciliolata but bearing the scattered fine, long hairs typical of $H$. pilosa, and several recent collections from the Roggeveld and Bokkeveld Mtns are intermediate, with plane, weakly ribbed, shortly ciliate leaves. This expanded circumscription of H. pilosa makes it impossible to continue to recognize H. ciliolata.

Among collections identified as Hesperantha pilosa from the Roggeveld, one collection (Goldblatt 5810) from near Middelpos was noted by Goldblatt as unusual in its secund spike of nodding flowers, and leaves with winged leaf margins and raised main vein. After examining the specimens again while reviewing variation in $H$. pilosa we note that the flowers have a curved perianth tube, creamy white perianth, and style branches \pm $4 \mathrm{~mm}$ long, thus half to two-thirds as long as other $H$. pilosa subsp. bracteolata in the Roggeveld and elsewhere. We describe this population as a separate species, H. secunda.

3. Hesperantha pilosa subsp. bracteolata (R.C.Foster) Goldblatt \& J.C.Manning, comb. et stat. nov. H. bracteolata R.C.Foster in Contributions from the Gray Herbarium 166: 6 (1948). Type: South Africa, [Northern Cape], Farm Uitkyk, Marloth 9907 (B, holo.!; PRE, iso.!).

Hesperantha puberula Schltr. ex R.C.Foster: 22 (1948). Type: South Africa, [Northern Cape], Oorlogskloof, Schlechter 10952 (B, lecto.! designated by Goldblatt: 57 (1984); B!, BOL!, G!, GRA!, K!, PRE!, US!, iso.).
Hesperantha ciliolata Goldblatt: 59 (1984), syn. nov. Type. South Africa. Northern Cape, Roggeveld Escarpment, Farm Geelhoek, 21 Sept. 1953, Acocks 17176 (PRE, holo.!).

Plants 70-200(-300) mm high. Corm ovoid, \pm 6 $\mathrm{mm}$ diam; tunics woody, concentric. Stem unbranched, glabrous or sparsely hairy. Foliage leaves 3, lower 2 linear to narrowly sword-shaped, blades plane or with main vein and margins raised, or oval in cross section and ribbed, 1-4 mm wide, pubescent or minutely ciliate, cilia horizontal on edges of ribs or margins, margins sometimes \pm winged, upper leaf partly sheathing lower half of stem, usually ribbed; with minute, scale like bract on upper 1/3 of stem. Spike (2)3-5-flowered, bracts subequal, $8-10 \mathrm{~mm}$ long, outer green or becoming \pm pale and membranous, inner membranous with 2 green keels, forked at apex or entire. Flowers blue or purple (rarely white), without darker pigmentation on reverse, salvershaped, unscented or with acrid, sour odour, opening 10:00 to $11: 00$ and closing mid to late afternoon; perianth tube 6-8 mm long; tepals (11-)12-16 × 3-5 mm, inner slightly shorter and wider than outer. Stamens with filaments 2.0-2.5 mm long; anthers (4)5-7 mm long, usually ascending to suberect, pale yellow or white; pollen yellow to white. Style dividing 1-2 mm below mouth of perianth tube, branches ultimately spreading, (7)8 9(11) $\mathrm{mm}$ long, reaching to upper third of anthers, sometimes exceeding them, \pm white, rarely purple. Capsules sub-globose, 5-6 × 4.5-5.0 mm. Seeds angular, $\pm 1 \mathrm{~mm}$ long. Flowering time: mid-August to late September.

Distribution: subsp. bracteolata extends from the Bokkeveld Mtns northwest of Nieuwoudtville through the Roggeveld south into the Klein Roggeveld and locally into the Voetpadsberg east of Touws River (Figure 3), usually in sandy, stony ground.

Diagnosis: distinguished from subsp. pilosa by the blue or purple (rarely white) perianth, the outer or all tepals not or only slightly more darkly pigmented on the reverse, subsp. bracteolata also usually has particularly long style branches, up to $11 \mathrm{~mm}$ long and reaching the upper third of the anthers when lined up together, or even exceeding them. Some plants may have relatively prominently ribbed leaves, the rib edges with short cilia directed horizontally as well as long hairs on the veins, a feature not seen in subsp pilosa. Flowers are occasionally white or pale blue to almost white but are always diurnal, open during the morning and closing after 12:20, sometimes after 14:00. In contrast, flowers of subsp. pilosa are crepuscular, opening in the evening, after 17:00 or at sunset, and then strongly scented (Goldblatt et al. 2004) and the tepals are white (creamywhite), rarely pale mauve, with the outer or all tepals darkly pigmented red to brown or purple. Populations with pale mauve tepals occur at scattered sites in the southwestern Cape (e.g. Barker 10653 (NBG), Swartwater Farm near Darling; Acocks 24314 (MO, PRE), Lucasfontein, Malmesbury; Goldblatt 2501 (MO, NBG), Theewaterskloof, Caledon). Tepals of subsp. pilosa are mostly $9-15 \times 2-4 \mathrm{~mm}$ and the style branches are 5-9 $\mathrm{mm}$ long, these dimensions overlapping those of subsp. bracteolata, which has tepals (11-)12-16 $\times \pm 3-5$ and style branches (7-)8-9(-11) mm long. 


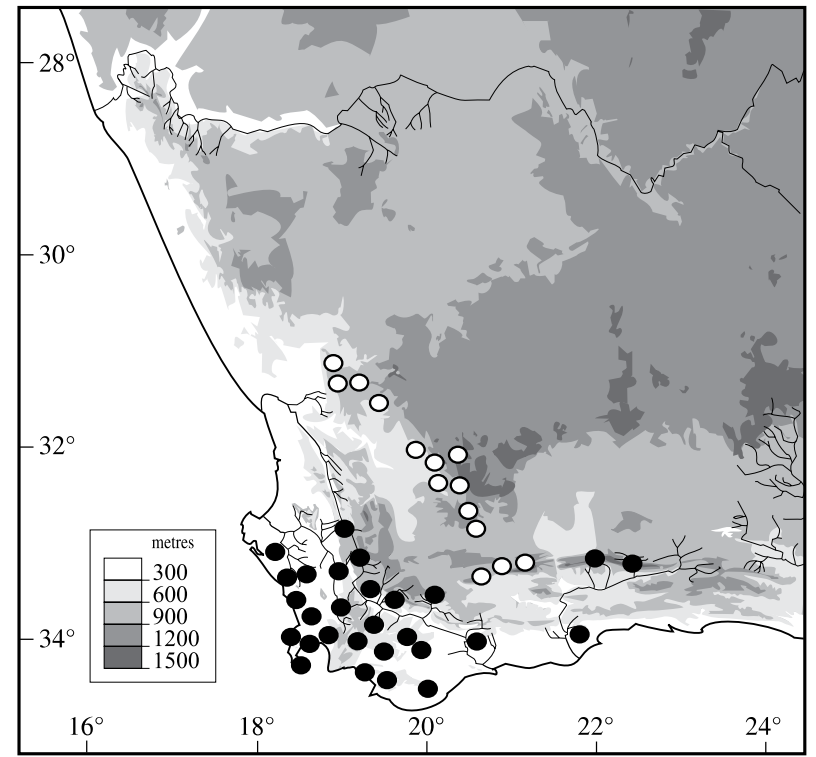

FIGURE 3.-Distribution of Hesperantha pilosa subsp. pilosa, •; and subsp. bracteolata, .

As noted by Goldblatt (2003) the type of subsp. bracteolata consists of short plants about $70 \mathrm{~mm}$ high, but a later collection from near the type locality includes taller, more robust plants, some up to 150 $\mathrm{mm}$ high, evidently growing in a wetter season. Foster (1948) named the species for the tiny scale in the upper half of the stem but that feature is actually typical of $H$. pilosa and some related species. The type plants match several other collections from the southern Roggeveld in their purple perianth. The type of $H$. puberula from the Bokkeveld Mtns south of Nieuwoudtville has the blue perianth characteristic of other collections from the area. There are also a few records of white-flowered plants within the range of subsp. bracteolata but these, like those with blue to purple flowers, have a diurnal flower phenology and lack red to dark brown pigmentation on the outside of the outer or all tepals. Flowers of subsp. bracteolata are blue in the Bokkeveld Mtns and the Roggeveld as far south to Ganagga Pass, purple west of Sutherland close to the escarpment and pale blue to white in the Klein Roggeveld and nearby. Plants from sites between Matjiesfontein and Touws River have blue flowers, thus matching those from the Bokkeveld Mtns. Flowering phenology has been recorded as opening 7:30, closing 12:30 in the Bokkeveld Mtns, closing mid-afternoon west of Sutherland and after 14:00 in the Klein Roggeveld.

\section{Additional collections seen}

NORTHERN CAPE.-3119 (Calvinia): Bokkeveld Escarpment, W of Farm Grasberg, (-AC), 1 Sept. 2005, Goldblatt 12682 (MO NBG); Grasberg road, NW of Nieuwoudtville, (-AC), 13 Sept. 1981, Goldblatt 6262 (MO), 12 Oct. 1983 (fr.), $7072 A$ (MO); $\pm 5 \mathrm{~km} \mathrm{~N}$ of Papkuilsfontein, (-AC), 27 Aug. 2009, Davidson 11595 (MO); Farm Driefontein, dolerite foothills at E end of Driefontein-se-Berg, (-DA), 16 Sept. 2009, Goldblatt, Manning \& Porter 13382 (MO, NBG). 3220 (Sutherland): Roggeveld Escarpment, just above top of Ganagga Pass, (-AA), 1 Sept. 1993, Goldblatt \& Manning 9680 (MO, NBG); Farm Hottentotskloof, Bo-Visrivier road, W of Sutherland, wet clay flats, (AC), 2 Oct. 1999, Goldblatt \& Nänni 11191 (MO, NBG); Farm Voëlfontein, valley $\mathrm{S}$ of farmhouse, wet places, (-AD), Goldblatt 6316 (MO); Roggeveld Escarpment, Farm Blesfontein, SW of Sutherland,
(-CD), 24 Sept. 2011, Goldblatt \& Manning 13669A (MO, NBG); top of Verlate Kloof, S of Sutherland, (-DA), 2 Oct. 1999, Goldblatt \& Nänni 11189 (MO, NBG); Klein Roggeveld, Farm De Hoop, (-DC), 30 Aug. 2007, Goldblatt \& Porter 12920 (MO, NBG).

WESTERN CAPE.-3220 (Sutherland): top of valley N of Farm Fortuin, (-DC), 26 Aug. 2006, Goldblatt \& Porter 12707 (MO, NBG); $78 \mathrm{~km} \mathrm{~S}$ of Sutherland, S-slope in small valley, (-DC), Goldblatt \& Manning 9662 (MO, NBG); Klein Roggeveld, Farm De Hoop, (-DC), 30 Aug. 2007, Goldblatt \& Porter 12920 (MO). 3320 (Montagu): foot of the Voetpadsberg, $21.5 \mathrm{~km}$ E of Touws River, foot of sandstone slope, (-AB), 3 Oct. 1999 (fr.), Goldblatt \& Nänni 11200 (K, MO, NBG, PRE); 11 Sept. 2001, Goldblatt \& Porter 11877 (K, MO, NBG, PRE, WAG); Matjiesfontein to Touws River, sandstone outcrop, (-AB), 27 Aug. 2006, Goldblatt \& Porter 12712 (MO).

\section{Hesperantha secunda Goldblatt \& J.C.Manning,} sp. nov.

TYPE.-[Northern Cape], 3119 (Calvinia): Roggeveld Escarpment, $56 \mathrm{~km}$ from Calvinia on Blomfontein road to Middelpos, (-DD), 17 Sept. 1980, Goldblatt 5810 (NBG, holo.; K, MO, PRE, S, US, iso.).

Plants 100-180 mm high. Corm ovoid, 7-8 $\mathrm{mm}$ diam; tunics woody, concentric. Stem unbranched, glabrous, with minute, membranous, scale like bract up to $3 \mathrm{~mm}$ long on upper third of stem. Foliage leaves 3, lower two basal, linear to narrowly sword-shaped, falcate or straight, finely hairy, blades $2.5-4.0 \mathrm{~mm}$ wide, margins raised and winged at $90^{\circ}$ to surface, main vein also raised and with narrow wings parallel to surface, uppermost leaf sheathing lower part of stem for all or part of its length, several ribbed, finely hairy. Spike mostly 3-7-flowered, bracts subequal, 7-10 mm long, outer green or becoming \pm pale and membranous, inner membranous with 2 green keels, forked at apex. Flowers creamy white, nodding, tepals spreading at right angles to tube, presence of scent unknown; perianth tube cylindric, curving outward, 6-7 mm long; tepals 10-11 $\times$ 2.5-3.5 mm, inner slightly shorter and wider than outer. Stamens with filaments $\pm 3 \mathrm{~mm}$ long; anthers 5-6 mm long, evidently spreading, pale yellow; pollen yellow. Style dividing $\pm 1.5 \mathrm{~mm}$ below mouth of perianth tube; branches ascending, $\pm 4 \mathrm{~mm}$ long, reaching to base or lower quarter of anthers. Capsules and seeds unknown. Flowering time: September.

Distribution: known from one population from the Roggeveld Escarpment west of Middelpos (Figure 1), Hesperantha secunda is recorded on shallow, finegrained soil over rocky sandstone pavement.

Diagnosis: when first collected, Hesperantha secunda was referred to $H$. pilosa with comments on its unusual winged leaf margins and main vein and nodding flowers on a secund spike (Goldblatt 1984). Reviewing the variation in $H$. pilosa in light of the many new collections made since then, this collection remains unique and we conclude that it represents a separate species, evidently allied to $H$. pilosa but distinguished by vegetative and floral morphology. All collections of $H$. pilosa have plane to ribbed leaves, the margins slightly thickened but rarely winged, and upright flowers with a straight perianth tube. Details of the flowers of $H$. secunda are also unusual for $H$. pilosa, including the relatively short tepals, $10-11 \mathrm{~mm}$ long vs. $9-15 \mathrm{~mm}$ in H. pilosa and short style branches, $\pm 4 \mathrm{~mm}$ long and reaching the base or lower quarter of the anthers when lined up together 
(the style branches diverge in the open flower). In $H$. pilosa the style branches reach to the middle or upper third of the anthers or even exceed them and are 7-9(11) $\mathrm{mm}$ long. An illustration of the species appears in Goldblatt (1984: 55 as H. pilosa).

\section{RANGE EXTENSION}

Hesperantha pilosa subsp. pilosa: until now the recorded range of subsp. pilosa is from the central Cedarberg at Middelberg and Uitkyk Pass to the Cape Peninsula and east to the Great Swartberg at Blesberg and from Caledon east to Riviersonderend and Bredasdorp (Goldblatt 1984, 1987). There are now records from near Swellendam and from Herbertsdale at the foot of Cloete's Pass in the eastern Langeberg (Figure 3). The latter represents a range extension of nearly $200 \mathrm{~km}$ east of Riviersonderend, previously the most easterly recorded station. Cloete's Pass specimens are consistent with subsp. pilosa, having crepuscular flowers with a white perianth with dark brown on the reverse of the outer tepals, a perianth tube $\pm 10 \mathrm{~mm}$ long and tepals $\pm 10 \mathrm{~mm}$ long.

WESTERN CAPE.-3420 (Bredasdorp): S of Swellendam on road to Bontebok Reserve, (-AB), 26 Aug. 2000, Goldblatt 11433 (MO, NBG); 3421 (Mossel Bay): 2 km from Herbertsdale to Cloete's Pass, (-BA), 26 Sept. 2003, Goldblatt \& Porter 12599 (MO, NBG); N of Herbertsdale at the foot of Cloete's Pass, (-?AB), 30 Sept. 2004, Goldblatt \& Porter 13599 (MO, NBG).

\section{ACKNOWLEDGEMENTS}

We extend our gratitude to Elizabeth Parker and Lendon Porter for their assistance and companionship in the field; Nick Helme for bringing his discovery of the new
Hesperantha dolomitica to our attention; and Michelle Smith for preparing the maps. Collecting permits were provided by the Nature Conservation authorities of Western and Northern Cape Provinces.

\section{REFERENCES}

FOSTER, R.C. 1948. Studies in Iridaceae V. Some new or noteworthy species of Hesperantha. Contributions from the Gray Herbarium 166: 3-27.

GOLDBLATT, P. 1982. Corm morphology in Hesperantha (Iridaceae, Ixioideae) and a proposed infrageneric taxonomy. Annals of the Missouri Botanical Garden 69: 370-378.

GOLDBLATT, P. 1984. A revision of Hesperantha (Iridaceae) in the winter rainfall area of southern Africa. Journal of South African Botany 50: 15-141.

GOLDBLATT, P. 1987. New species and notes on southern African Hesperantha (Iridaceae). South African Journal of Botany 53: 459-463.

GOLDBLATT, P. 2003. A synoptic review of the African genus Hesperantha (Iridaceae: Crocoideae). Annals of the Missouri Botanical Garden 90: 390-443.

GOLDBLATT, P. \& MANNING, J.C. 1986. Convergent evolution of the Homeria flower type in six new species of Moraea (Iridaceae) in southern Africa. Annals of the Missouri Botanical Garden 73: $102-116$.

GOLDBLATT, P. \& MANNING, J.C. 1993. Ixia acaulis, a new acaulescent species of Iridaceae: Ixioideae from the Knersvlakte, Namaqualand, South Africa. Novon 3: 148-153.

GOLDBLATT, P. \& MANNING, J.C. 2007a. New species and notes on Hesperantha (Iridaceae) in southern Africa. Bothalia 37:177182.

GOLDBLATT, P. \& MANNING, J.C. 2007b. A revision of the southern African genus Babiana, Iridaceae: Crocoideae. Strelitzia 18.

GOLDBLATT, P. \& MANNING, J.C. 2008. The Iris family: natural history and classification. Timber Press: Portland, London.

GOLDBLATT, P., NÄNNI, I., BERNHARDT, P. \& MANNING, J.C. 2004. Floral biology of Hesperantha (Iridaceae: Crocoideae): how minor shifts in floral presentation change the pollination system. Annals of the Missouri Botanical Garden 91,1: 186-206. 